International Proceedings of Economics Development and Research

\title{
International Proceedings of Economics Development and Research
}

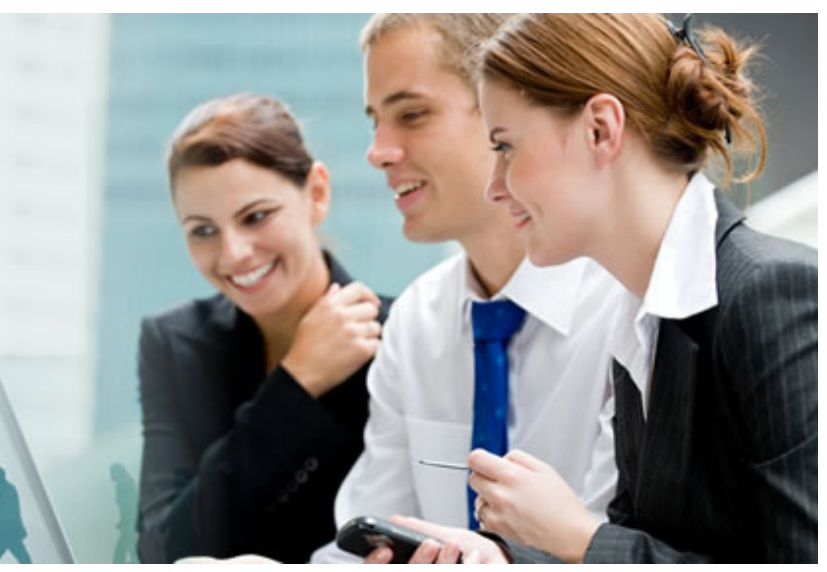

HOME > Archive > Volume $68>$

\section{Upcoming Conferences}
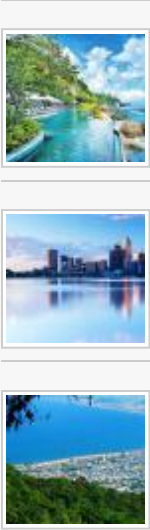

ICEEL 2018

05 Nov - 07 Nov 2018

Bali, Indonesia

Submission due:30 Jul 2018

\section{ICBMG 2018}

19 Nov - 21 Nov 2018

Perth, Australia

Submission due:20 Aug 2018

\section{ICOSH 2018}

05 Dec - 07 Dec 2018

Da Nang, Vietnam

Submission due:20 Oct 2018

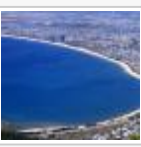

\section{ICHC 2018}

05 Dec - 07 Dec 2018

Da Nang, Vietnamn

Submission due:20 Oct 2018

\section{ICMBT 2019}

10 Jan - 13 Jan 2019

Tokyo, Japan

Submission due:10 Oct 2018

\section{What News}

Jun 13, 2016 News!Vol. 85 is available online

now. [Click]

May 29, 2015 News!Vol. 84 is available online now. [Click]

May 29, 2015 News!Vol. 83 is available online now. [Click]

\section{Volume 68}

뭅 Contents

\begin{tabular}{|c|c|c|}
\hline Article\# & Article Title \& Authors & Page \\
\hline 1 & $\begin{array}{l}\text { Sentiment Classification in Chinese Microblogs: Lexicon-based and Learning-based } \\
\text { Approaches } \\
\text { Bo Yuan, Ying Liu and Hui Li } \square\end{array}$ & 1 \\
\hline 2 & $\begin{array}{l}\text { Developing Autonomy in an East Asian Classroom: from Policy to Practice } \\
\text { Thao Thi Thanh PHAN }\end{array}$ & 6 \\
\hline 3 & $\begin{array}{l}\text { Students' Perspective of the Use of Audio visual Aids in Pakistan } \\
\text { Ghazala Kausar }\end{array}$ & 11 \\
\hline 4 & $\begin{array}{l}\text { Language Modes and Intertextual Translation of Corporate Leaders' E-Messages in Hong } \\
\text { Kong and China } \\
\text { Sing-Bik, Cindy NGAI } \square \text {, and Rita Gill SINGH }\end{array}$ & 14 \\
\hline 5 & $\begin{array}{l}\text { The Schnabel Method: An Ecological Approach to Productive Vocabulary Size Estimation } \\
\text { Juan Carlos Olmos Alcoy }\end{array}$ & 19 \\
\hline 6 & $\begin{array}{l}\text { Language and Socio-cultural Attitudes of Youth in Jammu and Hyderabad, India towards Rap } \\
\text { Music } \\
\text { Udita Sawhney }\end{array}$ & 25 \\
\hline 7 & $\begin{array}{l}\text { Enhancing ESL Learners' Writing through Technology } \\
\text { Preet Hiradhar }\end{array}$ & 30 \\
\hline 8 & $\begin{array}{l}\text { Engaging Emergent Readers with Texts Using Shared Reading: Indonesia's Case } \\
\text { Herli Salim } \square \text {, and Widjoyoko, Deny Wardana }\end{array}$ & 37 \\
\hline 9 & $\begin{array}{l}\text { Oral Communication Skills in the Financial Services and Telecommunication, Technology, and } \\
\text { Media Industries } \\
\text { Isarji Hj Sarudin and Zainab Mohd Noor }\end{array}$ & 42 \\
\hline 10 & $\begin{array}{l}\text { A Case for Using First Language Group Discussions to Facilitate Second Language Reading } \\
\text { Comprehension } \\
\text { Moyra Sweetnam Evans }\end{array}$ & 47 \\
\hline 11 & Investigating Status Planning through Studying Language Attitudes & 53 \\
\hline 12 & $\begin{array}{l}\text { An Empirical Study on the Multidimensional Learning Styles of Chinese EFL Students } \\
\text { Juan Zhang } \square \text { and Moyra Sweetnam Evans }\end{array}$ & 61 \\
\hline 13 & $\begin{array}{l}\text { Questions in Teacher Talk: What Questions are Frequent and how it Affects Critical Thinking } \\
\text { Yasmin Mari U. Ambrosio }\end{array}$ & 70 \\
\hline 14 & $\begin{array}{l}\text { Clothing as Identity and Gender in The Merchant of Venice Shu-hua Chung } \square \text { Degree } \\
\text { Program of Performing Arts; Tung-Fang Design Institute Abstract. In Renaissance England, }\end{array}$ & 76 \\
\hline
\end{tabular}




\begin{tabular}{|c|c|c|}
\hline & $\begin{array}{l}\text { besides the function as currency and as fashion, clothing, a sign symbolizing meaning, } \\
\text { Shu-hua Chung }\end{array}$ & \\
\hline 15 & $\begin{array}{l}\text { Interest Maintained and Anxiety Comparison of Static Versus Animated Agents in Gameplay } \\
\text { Jon-Chao Hong } \square, \text { Ming-Yueh Hwang, and Kai-Hsin Tai }\end{array}$ & 83 \\
\hline 16 & $\begin{array}{l}\text { Language Attitudes of University Students in China } \\
\text { Fong Peng Chew }\end{array}$ & 89 \\
\hline 17 & $\begin{array}{l}\text { A Study of Chinese Reading Strategies Used by Thai Undergraduates } \\
\text { Xu Ping }\end{array}$ & 98 \\
\hline 18 & $\begin{array}{l}\text { Reading in Engineering: Understanding Engineering Students' English Language Academic } \\
\text { Literacies } \\
\text { Wahiza Wahi }\end{array}$ & 107 \\
\hline 19 & $\begin{array}{l}\text { The Assessment Tool of L2 Learners' Pragmatic Competence: Written Discourse Completion } \\
\text { Test (WDCT) } \\
\text { Fauzul Aufa }\end{array}$ & 113 \\
\hline 20 & $\begin{array}{l}\text { An Investigation of the Relationship between Metacognitive Strategies and Vocabulary Size in } \\
\text { an ESL Environment } \\
\text { Engku Haliza Engku Ibrahim, Isarji Sarudin, Ainon Jariah Muhamad, and Zaleha Esa }\end{array}$ & 118 \\
\hline 21 & $\begin{array}{l}\text { Phonological Features of in-, un- and non- } \\
\text { Akira Okada }\end{array}$ & 123 \\
\hline 22 & $\begin{array}{l}\text { Stigmatised Linguistic Identities and Spanish Language Teaching } \\
\text { Macarena Ortiz Jiménez }\end{array}$ & 129 \\
\hline 23 & $\begin{array}{l}\text { An Analysis of a Work Composed in Sengin Semâî Rhythm with } 6 / 4 \text { Scale as an Example of } \\
\text { the Relationships between the Tempo/Rhythm and Aruz Prosody in the Poems of Classical } \\
\text { Turkish Literature Written for Composing } \\
\text { Elif Bilge KURTULDU } \square \text { and Oguz KARAKAYA }\end{array}$ & 136 \\
\hline 24 & $\begin{array}{l}\text { Harnessing Children's Literature for Nigeria's Transformation Agenda } \\
\text { Asabe Yusuf Mohammad }\end{array}$ & 140 \\
\hline 25 & $\begin{array}{l}\text { 'A Pet Rabbit, Bunny': Teaching English to Orang Asli Children, an Indigenous community in } \\
\text { Malaysia } \\
\text { Sumathi Renganathan }\end{array}$ & 145 \\
\hline 26 & $\begin{array}{l}\text { Reader-response Criticism in Teaching Literature for EFL/ESL Students at the University Level } \\
\text { Dinh Thi Minh Hien }\end{array}$ & 152 \\
\hline
\end{tabular}




\title{
Oral Communication Skills in the Financial Services and Telecommunication, Technology, and Media Industries
}

\author{
Isarji $\mathrm{Hj}$ Sarudin $^{1+}$ and Zainab Mohd Noor ${ }^{2}$ \\ ${ }^{1}$ International Islamic University Malaysia \\ ${ }^{2}$ Universiti Teknologi MARA Malaysia
}

\begin{abstract}
The ability to speak well in English has been considered an indispensable asset, particularly in organizations that use English as the main language of communication. This paper presents the findings of a study to investigate the importance oral communication skills in the Financial Services and Telecommunication, Technology, and Media industries. Data for the study were gathered from 67 employers from the Financial Services and Telecommunication, Technology, and Media industries. The instrument to collect the data was a survey questionnaire consisted of 20 items on oral communication skills. The findings of the study, based on descriptive and inferential statistics reveal that oral communication skills were found to be statistically more important in the Financial Services than in the Telecommunication, Technology, and Media industries.
\end{abstract}

Keywords: Oral Communication Skills, English Proficiency, Workplace Competency, Employability Skills

\section{Introduction}

Higher education institutions play a crucial role in providing quality human capital because employers seek graduates who have not only basic academic, technical, and content knowledge, but also generic or soft skills such as teamwork, leadership, communication, higher order thinking, and personal qualities associated with ethics, values, responsibility, and self-confidence [1]-[6]. Malaysia employers are likely to rate communication skills in English as a top priority for hiring and retaining employees [7]-[12] and findings of studies by [7]-[16] indicate that Malaysian graduates have poor communication skills for workplace purposes.

[6]'s study on the English language needs of economics and business sciences graduates, for example, revealed that poor English language competency has hampered graduates of Malaysian higher education institutions to present ideas and explain issues orally, in writing, and in group discussions; to write reports, project papers, proposals and minutes of meeting; to convey ideas spontaneously in impromptu situations; and to negotiate, lead and manage. [17] also found that unemployed graduates in Malaysia lack competency in English for oral business communication. Studies on information technology students in Malaysia found that many employers chose not to hire local graduates because they had poor command of the English language, lack general knowledge, have poor problem-solving skills and apply for jobs that are not relevant to their experience [18]-[19]. Although the industries are in a serious need of employees especially in the fields of science, engineering and business, many employers are hesitant to hire graduates who are highly qualified academically due to their poor proficiency in English [1]. [19] states that employers look for candidates who have the abilities to generate and express ideas verbally in English, give presentations, write reports, speak English fluently and with good command of grammar. The findings of these studies undoubtedly underscore the importance of communication skills as the impetus for a successful career [20].

The literature on employability of graduates of Malaysian institutions of higher learning highlights the growing concern among employers of the lack of communication skills among graduates. This clearly indicates the need for institutions of higher learning to re-examine their English language programs to overcome the perceived weakness of graduates in terms of communication skills.

\footnotetext{
${ }^{+}$Isarji Hj. Sarudin. Tel.: +603 6196 4902; Fax: +603 61964865

Email address: isarji@iium.edu.com
} 


\section{Objectives}

The objective of the study is to conduct a needs assessment of oral communication skills in the Financial Services and Telecommunication, Technology and Media industries. The research questions are as follows:

- How important are oral communication skills in the Financial Services and Telecommunication, Technology and Media industries?

- How important are purposes, situations and criteria of oral communication skills in the Financial Services and Telecommunication, Technology and Media industries?

\section{Methodology}

The findings of the study are based on data collected from a 20-item survey questionnaire. A five-point Likert scale was used to measure the responses based on the scaling of 1 (not at all important), 2 (not so important), 3 (quite important), 4 (important), and 5 (very important). A total of 64 employers participated in the survey; 33 were from the Financial Services (FS) industry, while 31 were from the Telecommunication, Technology \& Media (TTM) industry.

\section{Findings}

The reliability test produces a Cronbach alpha of 0.970, signifying a high level of internal consistency of the items. The 20-item questionnaire then was subjected to descriptive and inferential analyses.

\subsection{The Importance Oral Communication Skills in the Industries}

The findings presented in Table 1 show that oral communication skills are quite important in the FS industry $(\mathrm{M}=2.85 ; \mathrm{SD}=.83)$ but not so important in the TTM industry $(\mathrm{M}=2.32 ; \mathrm{SD}=.86)$. The results of a series of t-tests indicate that the means difference in the perceptions of employers in the FS and TTM industries were statistically significant $(\mathrm{t}=2.52$; $\mathrm{df}=64 ; \mathrm{p}<0.015)$ (Table 1). Employers in the FS industry perceived oral communication skills significantly more important than employers in the TTM industry.

Table 1: The importance of oral communication skills in the Financial Services and the Telecommunication,

Technology, and Media industries ( $\mathrm{P}>0.05$, two-tailed)

\begin{tabular}{|c|c|c|c|c|c|c|c|}
\hline Skill & Industry & $\mathbf{N}$ & Mean & SD & Df & t-test & Sig (2-tailed) \\
\hline \multirow{2}{*}{$\begin{array}{l}\text { Oral } \\
\text { communication } \\
\text { Skills }\end{array}$} & Financial Services & 33 & 2.85 & 83 & \multirow[b]{2}{*}{64} & \multirow[b]{2}{*}{2.52} & \multirow[b]{2}{*}{0.015} \\
\hline & $\begin{array}{l}\text { Telecommunication, } \\
\text { Technology \& Media }\end{array}$ & 31 & 2.32 & .86 & & & \\
\hline
\end{tabular}

\subsection{The Purposes of Oral Communication Skills in the Industries}

The results tabulated in Table 2 indicate that speaking to communicate spontaneously, demonstrate, welcome visitors, persuade, make business arrangements, respond to questions and inform are oral communication skills considered quite important (range of $\mathrm{M}=2.89$ to $\mathrm{M}=3.31$ ) by employers in the FS industry. Employers in the TTM industry, on the other hand only perceived speaking to welcome visitors and make business arrangements as quite important $(\mathrm{M}=.2 .52$ and $\mathrm{M}=2.50)$.

Overall, employers in the FS perceived purposes of oral communication skills as quite important, while employers in the TTM industry perceived the skills as not so important. Based on t-tests, the mean difference in the perceptions was statistically significant $(\mathrm{t}=2.85, \mathrm{df}=64, \mathrm{p}<0.006)$ (Table 2$)$.

\subsection{The Situations in Which Oral Communication Skills are Used in Industries}

The importance of oral communication skills in seven workplace situations were analyzed (Table 2). Employers in the FF industry reported oral communication skills are quite important in formal discussions $(\mathrm{M}=3.14 ; \mathrm{SD}=1.19)$ and meetings $(\mathrm{M}=2.57 ; \mathrm{SD}=1.09)$, while none of the situations to use oral communication skills were considered important (range of $M=1.90$ to $M=2.26$ ) in the TTM industry. The overall means for FS and TTM industries were $(\mathrm{M}=2.31, \mathrm{SD}=.83)$ and $(\mathrm{M}=2.19, \mathrm{SD}=.791)$, respectively. Based on t-tests, the means difference were not statistically significantly (Table 2) 
Table 2: The importance of oral communication skills ( $\mathrm{P}>0.05$, two-tailed)

\begin{tabular}{|c|c|c|c|c|c|c|c|c|}
\hline & \multirow{2}{*}{$\begin{array}{l}\begin{array}{l}\text { Oral Communication Skills } \\
\text { (OCS) }\end{array} \\
\text { Purposes of OCS } \\
\end{array}$} & \multicolumn{2}{|c|}{$\begin{array}{l}\text { Financial } \\
\text { Services }\end{array}$} & \multicolumn{2}{|c|}{$\begin{array}{l}\text { Telecom, Tech } \\
\text { \& Media }\end{array}$} & \multirow[t]{2}{*}{ t-test } & \multirow[t]{2}{*}{ Df } & \multirow[t]{2}{*}{$\begin{array}{l}\text { Sig } \\
\text { (2 tailed) }\end{array}$} \\
\hline & & Mean & SD & Mean & SD & & & \\
\hline 1. & To communicate spontaneously & 3.31 & 1.051 & 2.32 & 1.194 & 3.589 & 64 & .001 \\
\hline 2. & To demonstrate & 3.31 & .963 & 2.33 & 1.184 & 3.683 & 64 & .001 \\
\hline 3. & To welcome visitors & 3.06 & 1.235 & 2.52 & 1.122 & 1.854 & 64 & .067 \\
\hline 4 & To persuade & 3.03 & 1.071 & 2.43 & 1.165 & 2.145 & 64 & .037 \\
\hline 5 & To make business arrangements & 3.00 & 1.237 & 2.50 & 1.196 & 1.650 & 64 & .103 \\
\hline 6 & To respond to questions & 2.91 & 1.314 & 2.23 & 1.146 & 2.254 & 64 & .026 \\
\hline \multirow[t]{3}{*}{7} & To inform & 2.89 & 1.105 & 2.33 & 1.093 & 1.668 & 64 & .047 \\
\hline & OVERALL & 3.07 & .96 & 2.35 & 1.05 & 2.85 & 64 & .006 \\
\hline & Situations of OCS & & & & & & & \\
\hline 8 & in formal discussions & 3.14 & 1.192 & 2.26 & 1.237 & 2.957 & 64 & .00 \\
\hline 9 & in meetings & 2.57 & 1.092 & 2.23 & 1.309 & 1.169 & 64 & .043 \\
\hline 10 & in social functions & 2.34 & 1.027 & 2.26 & .855 & .362 & 64 & .716 \\
\hline 11 & in informal discussions & 2.17 & 1.098 & 2.26 & 1.064 & -.325 & 64 & .746 \\
\hline 12 & with superiors & 2.09 & .919 & 1.90 & .944 & .795 & 64 & .430 \\
\hline 13 & with colleagues & 1.97 & 1.014 & 2.35 & .915 & -1.605 & 64 & .111 \\
\hline \multirow[t]{3}{*}{14} & with subordinates & 1.91 & .919 & 2.13 & .846 & -.983 & 64 & .327 \\
\hline & OVERALL & 2.31 & .83 & 2.19 & .791 & .581 & 64 & .563 \\
\hline & Criteria in Assessing OCS & & & & & & & \\
\hline 15 & Correct use of grammar & 3.40 & .976 & 2.68 & 1.077 & 2.860 & 64 & .006 \\
\hline 16 & Clarity of ideas & 3.34 & 1.027 & 2.65 & 1.050 & 2.725 & 64 & .008 \\
\hline 17 & Fluency & 3.34 & .968 & 2.35 & 1.112 & 3.859 & 64 & .000 \\
\hline 18 & Appropriate use of vocabulary & 3.26 & 1.010 & 2.48 & 1.029 & 3.077 & 64 & .003 \\
\hline 19 & Coherence of ideas & 3.26 & 1.039 & 2.52 & 1.029 & 2.906 & 64 & .005 \\
\hline \multirow[t]{2}{*}{20} & Relevance of idea & 3.20 & 1.023 & 2.42 & 1.177 & 2.883 & 64 & .005 \\
\hline & OVERALL & 3.30 & .95 & 2.52 & .99 & 3.27 & 64 & .002 \\
\hline
\end{tabular}

\subsection{The Criteria in Assessing Oral Communication Skills in the Industries}

The findings of the analyses show that correct use of grammar, clarity of ideas, fluency, appropriate use of vocabulary, coherence of ideas, and relevance of ideas were quite important criteria in assessing oral communication skills in the FS industry (range of $\mathrm{M}=3.20$ to $\mathrm{M}=3.40$ ), while in the TTM industry, the employers reported correct use of grammar, clarity of ideas, and coherence of ideas as quite important criteria ( $M=2.68 ; M=2.65 ; M=2.52)$ (Table 2). The overall means for the FS and TTM industries were $(\mathrm{M}=3.30 ; \mathrm{SD}=.95)$ and $(\mathrm{M}=2.51 ; \mathrm{SD}=.99)$, respectively. Based on t-tests, the mean difference was statistically significant $(\mathrm{t}=3.27, \mathrm{df}=64, \mathrm{p}<.002)$, indicating that the overall criteria used to assess employee's oral communication skills were significantly more important in the FS than TTM industries.

\section{Conclusion}

The main objective of the study was to investigate the importance of oral communication skills in the FS and TTM industries. The findings reveal that oral communication skills were significantly more important $(\mathrm{t}=2.52 ; \mathrm{df}=64 ; \mathrm{p}<0.015)$ in the FS than in the TTM industries, particularly, in terms of the purpose of oral communication skills $(\mathrm{t}=2.85, \mathrm{df}=64, \mathrm{p}<0.006)$ and criteria to assess the skills $(\mathrm{t}=3.27, \mathrm{df}=64, \mathrm{p}<.002)$. Speaking to demonstrate, persuade, inform, respond to questions, make business arrangement, welcome visitors, and communicate spontaneously were found to be quite important oral communication skills in the FS industry, especially in formal meetings and discussions. Correct use of grammar, clarity of ideas, fluency, appropriate use of vocabulary, coherence and relevance of ideas were also found to be quite important criteria in in assessing employees' oral communication skills in the FS industry. Based on these findings, it is reasonable to assume that employers in the FS industry are likely to expect graduates to possess fluency and accuracy in oral communication. 
English will always be the most important language at the workplace in Malaysia as long as the language of business is determined by the market forces. The findings of this study provide the empirical evidence of the importance of oral communication skills in the Financial Services industry. It is important for English language programme providers need to be cognizance of the expectations of employers when designing or reviewing the course syllabus. Likewise, employers need to be pro-active in communicating their expectations to institutions of higher learning. This is especially true considering the fact that the students have three to four years at institutions of higher learning before they embark on a career in the industry. The constructive synergy between institutions of higher learning and business organizations will certainly enhance employability of $21^{\text {st }}$ century graduates.

\section{References}

[1] Kaur, S. and Clarke, C. M. Analysing the English Language Needs of Human Resource Staff in Multinational Companies. English for Specific Purposes World Journal Issue. 2009, 3 (24), Volume 8. http://www.espworld.info Retrieved November 10, 2009.

[2] Nayan, Surina.. Employability Awareness among Malaysian Undergraduates. International Journal of Business and Management. August 2010. Vol.5, No.8.

[3] Gurvinder Kaur Gurcharan Singh \& Sharan Kaur Garib Singh. Malaysian graduates’ employability skills http://www.ejournal.unitar.edu.my/articles/Gurvindermalaysian/Graduate.pdf. August 15, 2008. Retrieved September 10, 2012.

[4] Chang, Mark. Why some graduates are more marketable than others. http://www.epu.jpm.my/new20folder/seminar/stm/WhySomeGraduatesaremoremarketable.pdf 2004. Retrieved November 23, 2010.

[5] Hariati Azizan and Lee Yen Mun. Top jobs for those who know the language well. The Sunday Star, April 10, 2011.

[6] Isarji Sarudin, Ainol Madziah Zubairi, Mohamad Sahari Nordin, Tunku badariah Tunku Ahmad. English language Competency for Employment Purposes: meeting the needs of the industry. In Nuraihan Mat Daud, Isarji Sarudin, Ainon Jariah Muhamad, Engku Haliza Engku Ibrahim, and Khairiah Othman (eds.). Language Studies in the Muslim World. IIUM Press: International Islamic University Malaysia. 2011, pp.179-208.

[7] Azizan, H.. Congratulations, you fit our bill! The Star. 2007, Feb. 4, p.10.

[8] Mehta, D., \& Mehta, N.K. Communication skills for Engineering professionals. http://www.adit.ac.in 2007. Retrieved May $23^{\text {rd }}, 2012$

[9] Hafizoah Kassim and Fatimah Ali. English Communicative Events and Skills Needed at the Workplace: Feedback from the Industry. English for Specific Purposes, 2010. 3 (29) :168-182.

[10] Md Zabid, Abdul Rashid and Ling, C.N. Malaysian employer perceptions about local and foreign graduates. Journal of Education for Business. 2003.

[11] Graddol, D. English Next British Council. http://www.britishcouncil.org.files/documents/learning-research english-next.pdf. 2006. Retrieved May 23, 2012.

[12] Altbach, P. Notes on the future of SQU: Comparative perspectives. In Towards a Long-term Strategic Plan for Sultan Qaboos University: Proceedings of the international workshop. Muscat:Sultan Qaboos University Press, 2010, pp. 3-9.

[13] Suzana Ab. Rahim and Farina Tazijan. Analyzing the training and internship needs assessment of verbal communication skills amongst hotel practitioners. English Language Teaching (Online Journal) 2010, Vol. 4, No.3, 44-53.

[14] Lorache. Managing Cultural Diversity in Teaching Professions, New York: Heinemann. 2003. 44-53.

[15] Kalantzis, M., \& Cope, B. Changing the Role of Schools. In B. Cope and M. Kalantzis (Eds.), Multiliteracies: Literacy Learning and the Design of Social Futures .London and New York: Routledge. 2000, pp.121-148.

[16] Moy, Patsy. Banks told to improve their English language experts; Language experts warn they risk losing 
overseas customers after survey finds glaring errors in promotional material. South China Morning Post, News section. April 12, 2003, p. 4

[17] David, M,K. \& Govindasamy. Negotiating a Language Policy for Malaysia: Local Demand for Affirmative Action versus Challenges from Globalization. In Canagarajah,A.S. (ed.), Reclaiming the local in language policy and practice. New Jersey: Lawrence Erlbaum Associates Mahwah. 2005, pp. 123-145.

[18] The Grad Dilemma. The Star. April 12, 2009.

[19] Wan Irham Ishak, Shafinah Md. Salleh \& Azhari Md. Hashim. Utilizing needs analysis study to determine the current English language needs in the industrial sector. Wahana Akademik Journal. 2006, (5), pp. 75-80.

[20] Strevens, P. ESP after twenty years: A re-appraisal. In M. Tickoo (Ed.), ESP: State of the Art. 2005. Singapore: SEAMEO Regional Language Centre. 